\title{
ROBERT LOWE, THE TIMES, AND POLITICAL ECONOMY
}

BY

JOHN MALONEY

\section{INTRODUCTION}

Most historians know Robert Lowe (1811-1892) as .Gladstone's first Chancellor (1868-73) and the leading orator against the Reform Bill of 1867. Educationists to this day criticise or praise his Revised Code of 1862, which introduced payment by results in schools. Historians of economic thought add Lowe's critique of relativism (evinced by his views on Ireland) and his stridently classical statements of the role of political economy from his later dispute with the English historical school.

Lowe was a hard, fierce man with a gift for enmity. Disraeli designated him the one Liberal whose hand he would refuse to shake. Victoria vastly preferred even Gladstone. "If he noticed that flames were crackling around him he reached out and fanned them" is Winter's (1976) comment on Lowe's career as a whole. If so, his years as a barrister and legislator in New South Wales (1842-50) were the ones when he reached for the kerosene. His sojourn even included two challenges to duels. One was avoided when his opponent was 
arrested on the way to meet him, the other declined by Lowe on the grounds that his opponent, though now an alderman, had

School of Business and Economics, University of Exeter, Streatham Court, Rennes Drive, Exeter EX4 4 PU, England.

previously been a non-commissioned officer. And the ministerial style which would dominate his career was set when, to a deputation of Australian bankers who claimed they "could not live" if a certain proposal went through, he snapped "And pray, why should you live?" (Knight, 1966, p.255)

Lowe's roughness and sarcasm coloured every public argument in which he took part. It was the same after his return to England, where, in addition, he managed to infuse his own abrasive qualities into the discourse of economists. It was not just what he said but his manner of saying it which placed him, in the eyes of John Stuart Mill and Cliffe Leslie, on the pinnacle of "vulgar economics." But there is one complex, neglected and very profuse strand in Lowe's writings which gives a far more ambivalent portrait of the man and his thoughts. This is the series of leading articles Lowe wrote for The Times between 1851 and 1868.

Lowe's defective eyesight (he was an albino) and succession of ministerial posts did not stop him keeping up an average of three 
leaders a week over this seventeen-year period. They were of course anonymous and it is only from 1857 that the Times archives have a record of who wrote what. So distinctive is Lowe's voice however that anyone interested in puzzling out the authorship was not required to labour very hard at the breakfast table. And Lowe's editorials can normally be taken as an accurate and unconstrained version of his personal opinions. John Delane's summary was that Lowe was able to "shoot his own arrows" behind the shield of The Times, and his correspondence with Lowe confirms this. ${ }^{1}$

To economists, Lowe's most remarkable set of leaders are those about the commercial treaty with France in 1860. Coming a close second are his analyses of the financial side of the American Civil War. Both have a significance well beyond the actual topics in hand. On the treaty, Lowe's uncharacteristic changes of mind, and the variety of positions to which these reversals took him, provide a classic instance, telling to this day, of how Ricardians fail to cope with free trade by negotiation. The Civil War -- and its second front, personally opened up by Lowe, of the Union versus political economy -- was the occasion for a series of reflections on economics more complex than anything he later achieved when celebrating the centenary of the Wealth of Nations or doing battle with the historicists. 
The first half of this article, then, examines Lowe's political economy as set out in the leader columns of The Times. The second reassesses his later and better known pronouncements in the light of the first.

\section{LOWE AND THE ANGLO-FRENCH TREATY OF 1860}

The repeal of the corn laws, Lowe wrote in The Times soon after he arrived home from Australia, "overleaps the ordinary achievements of legislation as the Arc de Triomphe towers over the low-lying buildings at its feet." (Times, 26 February 1851, p.4) And in one of his first parliamentary speeches he praised Gladstone's great free-trading budget of 1853 for upholding "the grand principle of Free Trade - far more valuable than Free Trade itself - that no one class in the country should be made tributary to another class." 2 This, to Lowe, was the defining principle of Liberalism and the unalterable background against which his frequent changes of heart over current commercial diplomacy were to unfold.

But after the 1853 budget there was a hiatus in the attack on protection, even though Lord Palmerston's first ministry (1855-8) negotiated some minor commercial treaties outside Europe. However, when Palmerston returned to office in 1859 with Gladstone, now a Liberal, as his Chancellor, the push towards freer trade was 
determined and immediate. Its first result was Richard Cobden's commercial treaty of 1860 with France.

To the many purists still alive in the Liberal Party, as well as the economists J.R. McCulloch and Bonamy Price, any such treaty was more a betrayal than an extension of free trade. If cutting tariffs was right, as it always was unless the tariffs were needed for revenue, it remained right whatever the other country did. Some unilateralists were placated by the most-favoured-nation clause within the Treaty, ensuring that Britain would benefit from any subsequent treaties signed by France with third parties. But the consensus was that the treaty's rationale was more political and diplomatic than economic. Lord Clarendon, the Foreign Secretary, said as much in his admission that "The treaty is thoroughly unsound, and a great mistak, [but] rejecting it, making an enemy of the Emperor .. would be a far greater mistake." (Steele, 1991, p.97). A retrospective Gladstone was to be blunter still: "There were only two alternatives, one of them the French treaty and the other war with France." (Howe, 1997, p.173) This was Cobden's own position; indeed "Cobdenite" and "Cosmopolitan" became interchangeable terms for the view that free trade was a fetter of mutual dependence which would restrain nations from breaking loose into war with each other ${ }^{3}$

Even if he had not been outside the Cabinet, Lowe as VicePresident of the Board of Education would have been one of the lesser 
weights as Palmerston's Government oversaw the French treaty. But the Vice-President was leading a double life, odd even by the more relaxed standards of the time, as chief critic of the Treaty in the leader columns of The Times. Even odder, and highly uncharacteristic of Lowe, was the chief critic's habit of altering his position almost weekly.

At the most basic level there was no reversal. Lowe knew his Ricardo. Abolishing tariffs -- provided they were not needed to raise revenue - was an economic good whatever the other side did. Even to contemplate treaties which made free trade a multilateral, negotiated affair, was to send out an economically illiterate message and fix surviving protectionists in their delusions.

Nonetheless Lowe oscillated between four different positions. The treaty, consistently, was founded on faulty political economy, but $1 \ldots$ this condemned it per se $2 \ldots$ it was to be condemned even if it had not been founded on faulty political economy 3 ... it should however be approved for non-economic reasons 4 ... it was still an economic improvement on no treaty Lowe started in the third position. The Times, he wrote on 16 January 1860, was "not disposed, as at present advised, to regard with favour any proposition for a return to the exploded practice of negotiating commercial treaties, but as to the general character of the 
measure sketched out, there can be no difference of opinion, at least on this side of the Channel." In other words he was for it. Why, if the practice had been rightly exploded? Because, said Lowe, peace came before even political economy, and anything which freed up trade promoted peace. Bring Anglo-French trade up to the levels of AngloU.S. trade, and you will have rendered war "absolutely impossible." (Times, 16 January 1860, p.6)

A week later Lowe pulled himself together with a biting diatribe against the Treaty. Among those bitten was Robert Lowe no.3. Now Lowe 1 related how he had supposed that England, no longer being a child, had put away childish things. Instead the government was making war on political economy, which rightly ruled that tariffs were justified only to collect revenue. To negotiate with France over tariffs made no more sense than negotiating with France over what your poor rate should be.

It was in this editorial that Lowe made his sole fleeting reference to Robert Torrens's case for reciprocity, based on the demonstration that unilateral removal of tariffs could make a country poorer by worsening its terms of trade. Lowe merely commented that reciprocity was "the last colour that is assumed by the dying dolphin of Protection", and that, though Torrens' arguments for it were "not entirely without force", they were overwhelmed by the case for deciding "our own taxation in strict accordance with abstract 
science." Moreover, commercial treaties actually obstructed free trade: "If we are to have commercial treaties we shall negotiate at the greatest possible disadvantage unless we have imposed on ourselves most exorbitant duties." Finally, after observing that a trade treaty with protectionist France was like a treaty of religious toleration with the Pope, Lowe took up the argument that, if the Treaty gave our coal and iron access to France, only a pedant would complain about its misalignment with economic correctness. But who were the real economic obsessives here, Lowe asked. The opponents of the Treaty, or supporters who could think only of export earnings as they furnished a belligerent France with "the two most important elements of war - coal and iron”? (Times, 23 January 1860, p.6. )

The treaty now emerged in a very odd fashion. Gladstone's budget of February 1860 spelt out nearly everything that Britain was "conceding", as Lowe wouldn't have put it. But all that France had so far promised was that prohibitions of British imports would be replaced by duties not exceeding 30\%. The actual level of these duties would be announced unilaterally by France once she had investigated, industry by industry, what was needed to "equalise the conditions under which domestic and foreign producers worked." 4 Britain, with its own "offer" set out, had no threats or promises left to try and influence this process. Its manufacturers might be invited over to Paris to assist the French investigation, but in the end all 
Britain could do was check the French facts and figures and doubt their accuracy when convenient (which Cobden duly did in the autumn of 1860.)

Lowe was not in a very strong position to condemn this order of play which, after all, largely divorced the detailed proposals of each side from his demons of negotiation, threat and reciprocity. On the other hand, he may have felt that a treaty which legitimised these evils just by being a treaty, only to hand to France all the strategic advantages of declaring last, got the worst of all possible worlds. Such ambiguities in his mind would help to explain why his tergiverisations now picked up speed. Initially, in the wake of Gladstone's budget, Lowe softened still further, even (27 February 1860) crediting the treaty with improving British perceptions of France to the point where "instead of regarding her as a storehouse of every possible danger and mischief, we are now beginning to look upon her as a magazine of many good things, as a land whose wine we shall drink, whose manufactures we shall improve." He then changed his position a third time, back to unqualified hostility. By May he was condemning exactly the unilateralist aspects of the treaty which might have helped reconcile him to it. Britain, he said, was unambiguously cutting duties against France, and whether she got anything in return would "depend solely on the favour and generosity of our magnanimous ally." (Times, 7 May 1860, p.8.) And by August 
he was saying he had known all along that "we were bound to get the worst" from the "huckstering negotiation" which had so successfully returned Britain to the days when politics had been mixed up with finance.

Political economy was now re-enthroned as the sole arbiter of trading policy. It forbade negotiating over tariffs and that was that. "The truths of science are no more fitting subjects for international compact than the dictates of morality." But instead of following political economy, we had followed "the wisdom of Mr Gladstone, which is wisdom of another fashion from that of Adam Smith, Ricardo and Mill." Not the least damage done by Gladstone's wisdom was the revival of the business attitude which blamed government for all its troubles. Commercial circulars which blamed the treaty for slackness of trade might well be right. The point, however, was that blaming the government invariably preceded an extension of its role - quite apart from the "degradation" of merchants who had gone to Paris to beg favours from a foreign power. Whether the "peace" argument might still have trumped Adam Smith for Lowe is unclear because he now abandoned it. If this is a treaty for peace, he asked, why had we just raised defence spending by another $£ 1.2$ million to protect ourselves from France? (Times, 1 August 1860, p.8)

At the end of 1860 the final details of the French side of the treaty were published. Gladstone must have been gratified by Lowe's 
response that it might all have been a lot worse: "we have paid dear for this treaty but we cannot deny that we have got something to show for our money." But not as much as France, whose gains were beyond narrow financial calculation. Prohibitionist France had been a brave and confident nation hobbled by an unfounded and uncharacteristic timidity about the quality of her goods. But now, Lowe believed, all this would give way. "Limited competition will give confidence, and confidence will in its turn whet the appetite for more competition." (Times, 4 December 1860, p.8)

How right he had been about this, claimed Lowe, when in 1862 he reviewed the treaty's first two years. The grief of the French protectionists, far more avid to be proved right than to see their country prosper, only added to the satisfaction everyone else ought to be feeling.

"We can no longer recognise in the French Protectionist the lighthearted inhabitant

of the beautiful land of the orange and vine - the gay, gallant, thoughtless cavalier, ever ready to set Europe in a blaze, and to dance gaily round the conflagration.

There is a deep and guttural emphasis in the growl with which the French Protectionist receives every fresh development of Free Trade, which assures us that there must be some very solid prosperity at the bottom of so much ostentatious

discomfort." (ibid., 27 May 1862, pp.9-10)

After this final flourish Lowe no.4 took charge and was never again dislodged. His final editorial on the subject provided his strongest statement that once the truths of political 
economy were understood, all sides would rush to remove duties unilaterally and "we shall hear no more of Treaties of Commerce." (ibid., 19 February 1863, p.8)

Even with a writer as invigorating as Lowe, it would be tedious to chronicle every remark he made about the Cobden treaty, and we have not done so. We have, however, charted the twisting road he followed on an ordnance survey rather than a motoring map, because its details possess a significance larger than Lowe's own career. It is as much a fact today as in 1860 that, in matters of commercial policy, it is the dogmatic free traders who are the least robust while more malleable folk, paradoxically, take a course of stern resolve. And this is because commercial treaties, just by being treaties, pose a nighinsuperable dilemma for Ricardian economics. One horn we have seen - you cannot negotiate without encouraging the delusion that unilateral tariff-cutting is a sacrifice, rather than an economic gain regardless of what anyone else does. The other horn, however, is that cutting tariffs unilaterally is a sacrifice if, in doing so, you give up the chance to persuade others, however misguided their logic, to follow suit. In the end, therefore, it is the convinced free traders who take out the weights and the balance every time some detail within the situation changes, while those less certain, or less comprehending, of the Ricardian message forge blithely ahead with agreements on wine and multifibres, wheat and microprocessors. Anyone cognisant with, say, the modern Economist magazine's 
attitude to the World Trade Organisation, will feel on familiar ground as they read about the 1860 treaty and Lowe.

\section{FREE TRADE AND POLITICAL ECONOMY}

Free Trade to Lowe was the issue par excellence to drive home the scientific status of political economy. And "scientific" meant mathematical and irrefutable, not empirical and falsifiable. Thus doubters over the efficacy of abolishing the corn laws were people who

“ ... applied principles drawn from political experience to economical science.

They forget that they had passed out of that region of compromise and conjecture in

which the politician is ever doomed to dwell, and got into the region of absolute

truth, which works out the conditions deducible from its premises with something

very nearly approaching to mathematical precision." (Times, 14 October 1858, p.6)

The abolitionists in contrast had realised exactly what political economy was, had applied it to the issue in hand, and so had rightly "dealt more in abstract and general principles than any speeches that ever were addressed to a large multitude”. (ibid., 27 September 1861, p.6) Naturally this could be only as effective as the mental limits of the multitude allowed. And inevitably, some protectionists would congratulate the backward section of the working class, elevating their stupidity into a hard-headed refusal to be seduced by 
abstractions. Lowe feared that scientific truth would remain the preserve of the "classes qualified by education to comprehend". True, those who could not manage the principles might be converted by experiencing the benefits of free trade. "Nature makes Protectionists, knowledge and observation freetraders." But this was a slow business, with an implacable protectionist enemy: "death, which mows down day by day the ripened harvest of education and experience." (ibid., 3 March 1860, p.8) ${ }^{5}$

In his editorials discussing the nature and appeal of free trade, Lowe adumbrated a number of themes which were to dominate his political and intellectual career: absolutism in economics; empiricism as a useful second string for convincing those unable to accept the $a$ priori certainties which were the real political economy; pessimism about popular understanding of economic issues. Lowe never quite elucidated the circumstances in which ignorant humanity would or would not hit on eternal economic truths and translate them into law; what rather tied his analysis together was his complete confidence that once good economic laws were enacted, however accidentally, ex post perception of their overwhelming merits would make them unassailable.

"[This] kind of law, of which history unhappily affords us very few examples, is

founded on abstract truth, which it brings for the first time prominently and

practically before the world. Its influence strengthens with its duration, clamour 
and prejudice are hushed and die out, and that which was at first mistaken for a more

local and temporary arrangement is recognised in its true character as a rule of

universal utility, a solid step onward in the progress of the human race.

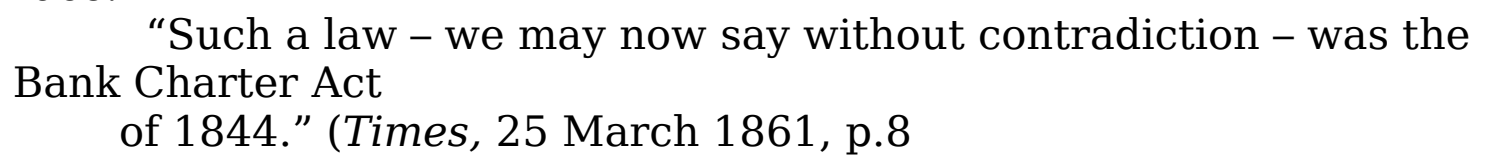

In this passage at least, Lowe is firmly on J.S.Mill's agenda, namely that the economist's

task is to discover the conditions of application of economic doctrines. (Prediction as the

purpose of economics was to come much later, and get Lowe into much posthumous

trouble.) Unlike Mill, however, Lowe thought it transparent that economists and the

economy had been working together steadily to broaden these conditions of application.

Thus when in 1864 he accused even Adam Smith of faint-heartedness, he also implied that

Smith's date of birth was both explanation and excuse:

"Nothing proves more clearly the title of political economy to the dignity of a science than the fact that the better it is understood and the more its abstract deductions are tested by experience, the more general and the better they become.

The theory came from its great author hampered with many exceptions, but the course of inquiry, which so often leads to the introduction of exceptions to general rules, has tended in this instance to prove that they never ought to have been made.

That the doctrines of Free trade do not apply to agriculture, that the interest of money ought not, like every other price, to be permitted to regulate itself according to demand and supply and, above all, that shipping should be secured to a country 
by the exclusion of foreign competition, are all heresies which have been held by

distinguished men and sanctioned by great names, but which have been successively

demolished by the power of reason and opinion, leaving the place they once took up

to be occupied by the wide principles the application of which they have vainly

sought to circumscribe." (Times, 9 June 1864, p.10)

But just as it took time to see the true merits of laws which enshrined the principles of

political economy, so an economy could survive for a while with laws that transgressed

them, as Lowe pointed out when, in the American Civil War, the Union made the dollar

inconvertible and yet their financial system did not immediately collapse.

\section{MONEY AND METHOD}

Lowe's first main engagement with monetary economics came in the series of leaders - thunderous even by his standards - that he wrote on the Northern side's financing of the American Civil War. The fact that they were about to resort to paper to continue the war, Lowe wrote in 1862, would lead anyone "reasonable" to abandon the fight without delay. Instead, the U.S. was about to "carry disorder, confusion and misery into the affairs of private life, to disorganise the relations between debtor and creditor, and to render general ruin as calamitous and disgraceful as possible." (Times, 5 February 1862, p.8) And, four months later: “... either the dismal science or the 
present things in America must be overthrown. The world is not wide enough to hold them both." (ibid., 24 June 1862, p.7)

This second front in the American civil war began with a quick victory for the dismal science, as paper depreciated $20 \%$ against gold, and the drain of gold out of the U.S. forced the government to prohibit further gold export. "Nemesis" Lowe rejoiced "has come at last." (Times, 31 July 1862, p.10) But a month later he conceded he had been premature. As the gold premium stabilised, Lowe counselled "not to expect that simply because we see a thing clearly it must necessarily follow speedily." (ibid., 22 August 1862, p.6) American tariffs had cut their import bill, smugglers were still organising themselves to beat the gold export embargo, and the California gold mines had gone into overtime. But Lowe's confidence was unshaken that the laws of political economy would defeat their violators in the end. What followed is so good a summary of Lowe's lifelong attitude to political economy that it is worth quoting at length.

"It is easy for a person moderately versed in the laws of economical science to apply

abstract principles to undoubted facts, and to draw from them conclusions in which

he feels the most perfect confidence. But the realisation of these conclusions as a

fact must depend on numberless circumstances of which general and abstract

speculation can take no account. The laws of political economy are sure ultimately

to assert themselves, but the laws of political economy are, after all, only the laws of

the human mind, and the predictions of the future which the science enables us to 
make are founded on the supposition that those laws take their uniform and usual

course. Political economy assumes that mankind, taken in the mass and in the long

run, will act according to that which they believe to be their true interest; but

political economy makes no allowance for all those things which blind men as to what their true interest is - vanity, patriotism, loyalty, hope, ambition, imagination, with all their exaggerating and distorting powers, are banished from the creed of the dismal science. These things tend to modify conclusions and to retard the action of general principles, but how far they do this every speculator must investigate and consider for himself." (ibid., 22 August 1862, p.6)

In this passage Lowe has distanced himself from Mill's methodological position in three ways. First, Mill holds that the principles of economics are subject to appropriate conditions of application, but holds out no certainty that these will eventually come about in any given context. Lowe does possess such certainty: the action of general principles can at most be "retarded." Secondly, while Lowe's political economy "makes no allowance" for noneconomic motives, Mill believed it must make such allowance if it were to influence the public and guide the legislator. It might be argued that the difference is definitional: the responsibilities Mill lays on political economy are laid by Lowe on the individual "speculator". The end-product is the same: what does it matter what is nominally placed within the definition of political economy and what the user is told he is required to add to it? But the third and greatest difference 
between Lowe and Mill cannot be dissolved into semantics. The noneconomic motives which both believe to be so important are, nonetheless, to Lowe, illusions which "blind men as to what their true interest is." It is one thing to say that patriotism or loyalty induce altruistic actions which may disrupt economic theories. It is quite another to take a lumpenmarxist line that these feelings are a form of "false consciousness". What Lowe probably meant was not that a patriot was a deluded fool - his own patriotic sentiments were often on display -- but that patriotic sentiments, like everything else, do not endure in the same way as do the imperatives of economic interest.

\section{PRINCIPLES OR CATCH-WORDS?}

Lowe's definition of political economy was sure and simple. It was the science that traced the consequences of the desire for gain. Its strength lay in the soundness of its basic postulate, and was revealed by the success of laws passed in accordance with the deductions made from that postulate. Particularly impressive was the way that those unable to grasp political economy nonetheless came to believe in it through the results of such laws - though the results might take a while and their clear perception still longer. And, because political economy deduced exact conclusions from first principles, it not only knew when an exception was an exception, but was well placed to find out why. When the world in general, and the 
results of legislation in particular, diverged from the deductions of political economy, economists sought and invariably found explanations of why ceteris had failed to be paribus.

Falsificationists' problems begin at this point but Lowe, like Mill, was no falsificationist.

Political economy, furthermore, had its own, rather booming, voice -- in fact it sounded startlingly like the voice of Robert Lowe. It "prescribed" freedom of contract, "forbade" negotiating over tariffs, and "ruled that" tariffs were only justified in order to collect revenue. Education was "no exception to the general rules of political economy". Gladstone's budget of 1860 had "contaminated the truths of financial science" and the commercial treaty it encompassed had dragged free trade down "from the dignity of a science to the foggy regions of diplomacy." Despite such mistakes, most of the laws of the pre-1867 parliament were framed "in accordance with the principles of political economy", notably the cuts in indirect taxes between 1846 and 1860, and the retention of Irish landlords' freedom to do what they liked with their land. ${ }^{6}$

Some of these statements sound stronger than others. "In accordance with the laws of political economy" suggests more room for manoeuvre than "prescribed" or "ruled" by political economy. But perhaps not too much weight should be placed on this. Lowe was writing leaders in The Times, not scholarly articles on the philosophy 
of science. Probably his exact choice of words was not as exact as all that. What he meant on each occasion was that the principles of political economy could be used to identify what would increase the wealth of the nation, or at least some part of it. (He would have clasped the idea of Pareto-efficiency with enthusiasm had it been around in his time.)

Lowe's conception of political economy came under fiercest attack when he applied it to Ireland. In fact, however, his differences with Mill (his chief critic) owed little to their different versions of economics -- a fact that Lowe realised more clearly than Mill did. Certainly it was far from a simple clash between an absolutist and a relativist. When in 1866 Lord John Russell's administration introduced a bill compensating evicted Irish tenants for improvements they had made, Lowe invited its supporters to put up a relativist case for the proposal. If, he said, it was being advanced in grounds peculiar to Ireland, "I can understand it. But if the ground is that of natural justice and right, it is not peculiar to one side of the Channel or the other." 7

Lowe's position was grounded in his belief that a modern system of capitalist agriculture (vainly recommended by Nassau Senior) was at last emerging. This was the real basis of his conflict with Mill, who never altered his view, stated at the height of the potato famine in 1847 , that capitalist farming was "wholly impracticable ... the people 
are there, and the problem is not to improve the country but to see how it can be improved by and for its present inhabitants." (Black 1960, p.31). Mill wanted to keep the peasants on the land, while pointing out that land laws the same as England's had very different results in Ireland. The tenantry's demand for land was so strong that the landlord could do what he pleased. Lowe concurred in the diagnosis but not the remedy. If the tenant's plight were caused by his insatiable demand for land, the only remedy was to reduce it. This could only be done by finding some would-be tenants alternative employment. If Ireland could not attract investment in manufacturing, the only solution left was mass emigration. Compensation for improvements would "put into action a set of causes which must infallibly drag Ireland down to the fearful position she held before 1846. You will give her back her lost millions, to be swept away by another famine." (Lowe 1868, pp.274-5) ${ }^{8}$

Lowe wrote this in 1868. By the end of the year he was Chancellor in a government whose mission was "to pacify Ireland." After much hard work in 1869, Lowe's Cabinet colleagues finally persuaded him to support a Bill compensating Irish tenants for improvements made to their land. The price of Lowe's support was a compromise Bill which specifically denied compensation to tenants evicted for non-payment of rent, and allowed the landlord to extend any tenant's lease to 31 years in order to escape claims for 
compensation. Outside Cabinet, with no negotiations to conduct or compromises to steer, Lowe remained closer to his underlying instincts. On the same day as he proposed the Compensation Courts he told Lady Salisbury that he had never been able to understand "the grievance of holding people to their contracts, nor able to find a better plan than leaving every man to do as he likes with his own time and labour.” (Burghclere 1933, p.232) The charge against Lowe, stretching from Mill in 1868, through Leslie (1879) to Moore (1996) was that he had shut himself off from such understanding by his conception of political economy. In a passage well known to historians of economic thought, Mill, speaking in parliament on 12 March 1868, declared that "political economy has many enemies, but its worst enemies are some of its friends, and I do not know that it has a more dangerous enemy than my hon. Friend." 9 Lowe, said Mill, had spoken "as if science was a thing not to guide our judgement, but to stand in its place". ${ }^{10}$ But:

"so far from being a set of maxims and rules to be applied without regard to times, places and circumstances, the function of political economy is to enable us to find the rules to govern any state of circumstances with which we have to deal ... it does not supply us with a ready-made judgement upon any case, and there cannot be a greater enemy to political economy than he who represents it in that light." '11 
Mill may or may not have felt these strictures described Lowe's economics in general: he was specifically criticising the speech Lowe had made immediately before his own. In this speech Lowe had pressed the laws of economics into the service of one thing only freedom to dispose of your property as you wish.

“... there is an oasis in the desert of politics upon which we may safely rest, and that is afforded by the principles of political economy. In accordance with the best ascertained principles of political economy, as well as of law, every man who has made money is entitled to invest it in land; and if you introduce arbitrary restrictions with respect to land, you artificially depreciate that description of property compared with other property. Freedom of disposition of land is a strong stimulus to that desire of accumulation on which the wealth of nations depend. I entertain a prejudice derived from Scotland and adopted by Adam Smith, that a man is at liberty to do what he likes with his own, and that having land, it is not unreasonable that he should be free to let his land to a person of full age upon the terms upon which they shall mutually agree. That I believe to be reason and good political economy." 12

One reason why political economy could bring to Ireland this sole - if supremely important - lesson was that Lowe excluded so much from the subject's scope.

"The questions so much agitated by Mr Mill, as to whether small cultivation is

better than large, are not political; no, nor, with all deference to him be it said, are

they politico-economical: they belong to the science of practical agriculture, and to 
the practical agriculturist we should leave them to work out for himself." (Lowe

1868, pp.272-3)

Even Lowe could hardly have expected Mill to be warned off the question on the strength of this, and in 1870 Mill returned to the attack on economists who

"believe themselves to be provided with a set of catch-words, which they mistake for

principles - free trade, freedom of contract, competition, demand and supply, the

wages fund, individual interest, desire of wealth, \&c. - which supersede analysis, and

are applicable to every variety of cases without the trouble of thought." (Mill 1870, p.671).

Perhaps this is aimed specifically at Lowe - Mill does not say. But does Lowe deserve it? We have seen little evidence of his using free trade or any other of the phrases on Mill's list as a substitute for analysis. The one "catchword" he did use to try and close arguments down was not the name of some topic in political economy but the name of political economy itself. And even here it is sparingly invoked. Precisely because Lowe does use it as a slogan, it in the end adds nothing essential to the edifice of his arguments over Ireland - 
an edifice which would look very little different had Lowe never referred to the scope, nature or methodology of economics in his life.

\section{LOWE AND ADAM SMITH}

And until 1878 Lowe showed little interest in the methodology of economics as such. Like anyone else, he had an implicit methodology of his own. This was determined negatively, by his very limited statement of conditions of application for his economic doctrines. To say that disturbing forces existed but, once identified, they merely reflected back the searchlight of economic analysis in increased splendour, was at once far less sophisticated than Mill's treatment and a superb provocation to the likes of Cliffe Leslie. If Lowe was not especially interested in methodology, the English historical school were not especially interested in anything else. And, central to their dispute with Lowe were the roles the two sides has assigned to Adam Smith.

On 31 May 1876 the Political Economy Club met to celebrate the centenary of The Wealth of Nations. Gladstone was in the chair. Lowe's speech was most remarkable for his characterisation of political economy as a finished subject. "The great work has been done." (Political Economy Club, 1876, p.21) This belief, in sharp 
contrast to Mill or Cairnes (not to mention Leslie, who wanted the great work to start all over again) informed Lowe's attitude to policy questions. The fact that he was often less narrow and dogmatic than his opponents claimed does not abolish the rift between his view that the precepts of political economy could be pulled off the shelf to guide the policies of the day, and the more cautious view of Mill (and later Marshall) that the issue in hand should force some hard thought over the scope and possible future direction of political economy. It is much easier to downgrade particular historical and geographical circumstances into "friction" if one has a finalised view of what the friction is rubbing up against.

But it was Lowe's characterisation of Smith himself which aroused the most ire at and after the centenary dinner. Smith, Lowe told the Political Economy Club, was the first and only man to discover a real science of mankind. To discover universal truths about humanity, to weld them into a system of analysis, and then to promulgate that system so that it caught legislators' minds demanded such rare gifts, in such unusual combination, that only one man in history had ever succeeded. In thus placing Ricardo and Mill so firmly in Smith's rearguard, Lowe was also reinforcing what he saw as the methodological unity of the classical school. ${ }^{13}$ In his address to Section $\mathrm{F}$ of the British Association for the Advancement of Science in 1878, J.K.Ingram followed Cliffe Leslie in driving the stoutest possible 
wedge between Smith, a historically-minded empiricist, and Ricardo, who instead built a mountain of deductions on the unreal stereotype of "economic man." In "Recent Attacks on Political Economy (1878), Lowe challenged Ingram "to produce a single instance from The Wealth of Nations where Smith has had recourse to the method of induction." (Lowe 1878, p.865) Induction meant inference: Smith observed, compared, explained and illustrated. The one thing he did not do was infer. Division of labour was a good example. First Smith asserted the principle, then he illustrated it. "Had he proceeded by the inductive method, he would have cited a number of trades in which the division of labour has been found of great advantage and from these instances would have deduced his principle." (ibid., p.866)

This is not much of a response. Whether actual instances of the division of labour come at the beginning or the end of chapter 1 of The Wealth of Nations tells us nothing as to how Smith arrived at the principle in his mind - as indeed Lowe proceeds to admit: "Adam Smith ... professorlike, was more solicitous to teach what he believed to be true than to impart the exact sources from which he derived his information." (ibid., p.866) ${ }^{14}$

Lowe then compares The Theory of Moral Sentiments and The Wealth of Nations. Why, asks Lowe, does the former work fail in its leading doctrine that sympathy forms the foundation of morals? (Smith's admirers might well interject at this point that they didn't 
know it had.) Because Moral Sentiments had "admitted of all motives except the single one of pecuniary interest", with the result that the deductive method "was not refined enough" for it. (ibid., p.867) In The Wealth of Nations, by contrast, Smith isolated the desire for gain, deduced its consequences, compared its predictions with the evidence, and in doing so was entitled to "the merit, and the unique merit of all men who ever lived in this world, of having founded a deductive and demonstrative science of human conduct"; the "noble attempt by Bentham and Mill to raise politics to a like eminence" having failed. (Political Economy Club 1876, pp.7-8)

With Smith boxed up in this fashion, it was an easy step to dismiss historical relativism - though Lowe denied he was doing this. On the contrary, he said, classical economics was itself relativist, insofar as its premises could only be "brought into existence" by the subject-matter they analysed:

"To suppose that political economists think otherwise is to impute to them a most melancholy economy of brains. All that political economy pretends to is that, when and in proportion as these things come into existence, the principles which apply to them come into existence with them." (Lowe, 1878, p.868) "I contend", says Moore (1996, p.87) "that these admissions were no more than cosmetic qualifications designed to meet the numerous criticisms of his approach." Taken purely in the context of "Recent Attacks on Political Economy" this is an arguable position (though 
even here one might comment that falsifying his beliefs was not exactly a leitmtoif of Lowe's, and, if he is not being accused of this, what exactly is "cosmetic" about his remarks?) But the testimony of Lowe's earlier writings in The Times shows his lifelong awareness that the conditions of application had to be right for political economy to make headway.

This, however, was not relativism as Ingram or Leslie would have understood it. Their relativism was the assertion that you needed different principles to analyse different times and places, each set of principles equally valid in its own context. Lowe in contrast was saying there was a single set of principles which could be applied once the world had constituted itself into something to apply them to. Until then, there were not alternative varieties of economics : there was no economics. ${ }^{15}$

\section{VULGAR ECONOMICS?}

So the birth of economic science had to wait for a tractable world, and for a genius to perceive that tractable world around him. But, once on its feet, the science had enjoyed huge success, colonising diverse areas of activity in a way which might have surprised its founder. At the Wealth of Nations centenary Lowe repeated his 1864 criticism that Smith had not been Smithian enough - though giving him credit for William Pitt's French treaty, abolition of monopolies in 
the colonies and indeed, once the germ of Smith's ideas had been fully worked out by others, the repeal of the corn laws and the establishment of limited liability. He also proclaimed himself optimistic that a better educated working class would learn from Smith the "errors and follies" of trade union behaviour. (Political Economy Club 1876, pp.14-19)

The most authentic Lowe thumbprint, however, had been in his 1864 piece-his remark that in other spheres investigation blew up exceptions into alternative rules but in political economy it closed them down. That this, more than anything else, proved the strength and soundness of the subject and its worthiness to be called a science, was a constant refrain of Lowe's. Above all political economy was, and would remain, a vastly more successful way of understanding the world than the sociology into which Ingram wanted to subsume it. Back in 1865 Lowe had ridiculed the Social Science Congress for "professing the cultivation of a branch of human knowledge which as yet has little existence except in its pretentious name." (Times, 2 October 1865, p.9) Now he suggested that Ingram might have accompanied his eulogium of sociology with some evidence that it existed. "It is a gross abuse of language ... to degrade the name of science by confounding it with crude and tentative attempts to create science." Sociology would have been created when it started making verifiable predictions, and when "the economical phenomena which 
are treated of in political economy are really dominated by some higher and more comprehensive generalisation." (Lowe 1878, p.860) Expect a long wait, Lowe warned, as long as sociology tried to apply to mankind the inductive method which could only work in the natural scientist's laboratory. Political economy had succeeded precisely because it recognised that human behaviour was so complex as to make a deductive approach not infeasible but unavoidable.

“...the facts are often intensely complicated ... separated from us often by vast intervals of space and time [and] subject to the distortion, falsification and exaggeration which interest, bigotry, love, hatred, ignorance and party spirit can introduce. We are expected, out of the shreds and fragments of ancient science, life and history which have come down to us mutilated, unvouched and unauthenticated, utterly hidden from the actors in those remote sciences themselves." (ibid., pp.861-2 )

And the measure of its success was what we now owed it:

"among other things, the repeal of hundreds of galling taxes on almost all the comforts of life and on the food of the people, the repeal of the corn and navigation laws, the cessation of smuggling, the placing of the currency on a thoroughly sound and satisfactory basis, the establishment of limited liability in joint-stock companies, the principle of payment by results, open competition for public appointments, and the abolition of the absurd system of bounties and drawbacks. These are some of the achievements of the past. I may be excused if I prefer them to the shadowy and unrealised anticipations of the future." (ibid., p.868) 
Lowe's article drew a swift response form Cliffe Leslie. Its theme was that orthodox economists who looked at Lowe would see only a mildly distorted version of their own basic principles - distorted, indeed, by an honesty which they themselves lacked. Certainly Lowe had exposed the absurdity of his own views, said Leslie, offering up targets like the remark that "if you place a man's ear within the ring of pounds, shillings and pence, his conduct can be counted on to the greatest nicety." (Leslie 1879, p.203) But there was no great distinction between Lowe's omission of all human motives except the desire for wealth, and the fate of these motives in the work of Mill and J. E. Cairnes, where they were "admitted at the outset for form's sake, to be afterwards set aside as 'disturbing causes' in a manner without precedent or analogy in physical science." (ibid., p.198)

However, in the matter of prediction in economics, Leslie did drive a qualitative wedge between Lowe and Mill or Cairnes. Lowe failed to realise, Leslie said, that his simplistic assumptions and his goal of prediction were incompatible: by throwing out so many motives he had no hope of success in the prediction he valued so highly. At least Mill had realised that conclusions derived from the $a$ priori method were "true only in the abstract" and would be "true without qualification only in purely imaginary cases." (ibid., p.198)

This limitation came about precisely because Mill had effectively removed so many human motives from the cognisance of political 
economy. And this situation would continue as long as economists clung to Cairnes' doctrine that "the economist starts with a knowledge of ultimate causes [and] is already at the outset of his enterprise, in the position which the physicist only attains after ages of laborious research." (ibid., p.202) On that basis, the foundation of all economics must be introspection and so -- unless deductivists imagined that they could also intuit all moral, religious, political and other motives influencing human conduct - they were stuck with a "science" effectively just as narrow as Lowe's version.

Leslie saw nothing wrong with prediction as one of the goals of economics, and indeed went out of his way to stress the power of prediction if the agenda were only widened. It was because marriages and births were the result of "love, chivalrous sentiment, morals and religion" that their incidence could be foretold. (ibid., p.211) But on the whole it was failure to understand, not failure to predict, which he condemned as the inevitable result of the method recommended by Lowe. Look at the German economy, so geared towards war. What would be the worth of a treatise deducing its characteristics "from the assumption that every man is occupied solely in the acquisition of wealth"? (ibid., p.210) Lowe (and by implication Mill and Cairnes) had ruled himself out from explaining why economies differed in their basic structure, occupational patterns and consumers' wants. (ibid., p.212) 
Lowe no doubt took the final charge with equanimity. He had already invited economists to share his indifference as to whether people preferred to grow pigs or tulips. (Lowe 1879, p.995). But Leslie also charged that Lowe's methodology stopped him having anything to say about why some economies grew while others stagnated. Enough has been said for the reader to imagine the depth of Lowe's indignation on this score. His entire defence of classical political economy rested on the idea that without its doctrines there would have been no liberal legislation and without liberal legislation Britain would be much less prosperous. Nor does Leslie disagree with this: his accusation is rather that Lowe has misunderstood the character of classical (or at any rate Smithian) economics. "Mr Lowe arrogates 'triumphs' for his own economic method: those he refers to were achieved by the opposite method of reasoning from observation and experience." (Leslie 1879, p.219)

Leslie could hardly have made himself clearer. Political economy could indeed claim legislative triumphs which had fostered the general good, and he and Lowe could agree what those triumphs were, whatever their differences about the underlying nature of the political economy which had produced them. It was left for Moore (1996) to adjudicate that Lowe had made mercantile success the only criterion of the success of political economy and thus justified 
Carlyle's jibe about "pig philosophy." On the basis of the remark quoted above, Leslie ought to join Lowe in the trough.

But Lowe was not a pig philosopher. He was an idiosyncratic, but not profoundly original, classical survivor who, like most of his contemporaries, saw nothing wrong with evaluating economics by the results of legislation passed in consonance with its principles. He would not go down well at a modern conference on the methodology of economics, but neither would a great many other people whose porcine qualities are not obviously to the fore.

As for Lowe's scorn for sociology, the present writer is going to infuriate his shade by suggesting that his own deepest convictions -taking precedence over even his economic liberalism - may properly be called sociological. There are two ways to get an economic liberal to talk about class. One is to put him in a society full of legal privileges for sectional interests. The other is to confront him with collectivist views themselves dominated by class. The second method barely worked on Lowe. He was enthusiastic enough in his search for intellectual positions to attack. They did not include socialism or communism, which he did use simply as catchwords (again wrongfooting Mill and his list). It was John Morley, not Lowe, who apprised Gladstone of the very interesting ideas of Dr Marx of Highgate.

But class privilege was a lifelong target. Hence his revealing statement that the doctrine that no one class in the country should be 
made tributary to another class was not only the grand principle of free trade, but far more valuable than free trade itself. Hence his anger when Lord Overstone tried to exclude the poor from shareholding and his insistence - more intense and protracted than any of his contemporaries - that the tax system be fair to all classes. There will always be those who say that the removal of sectional privileges itself privileges the class that alone does not have to rely on such assistance to begin with -- the ruling class, or the owners of the means of production, if one wants to put it in Marxist language. There is much to be said for this view but Lowe would not have said it. "The ideal of the Liberal Party" he said in 1877:

“... consists in a view of things undisturbed and undistorted by the promptings of interest and prejudice, in a complete independence of all class interests, and in relying for its success on the better feelings of mankind." 16 "Happier words" commented Matthew Arnold (not always a Lowe enthusiast) "could not well be found : such is, indeed, the ideal of the Liberal Party" 17

\section{REFERENCES}


Black, R.D.Collison. 1960. Economic Thought and the Irish Question. Cambridge :

Cambridge University Press

Black, R.D.Collison. 2002. “The political economy of Thomas Edward Cliffe Leslie

(1826-82): a re-assessment." European Journal of the History of Economic Thought,

$9,17-41$

Burghclere, Lady. 1933. A Great Lady's Friendships : Letters to Mary,

Marchioness of

Salisbury and Countess of Derby, 1862-90. London: Macmillan.

History of the Times. 1936-9. London: The Times (4 vols.)

Howe, Anthony. 1997. Free Trade and Liberal England 1846-1946.

Oxford: Oxford

University Press

Iliasu, A. 1965. 'The Role of Free Trade Treaties in British Foreign Policy, 1859-1871',

Ph.D. thesis, University of London.

Knight, Gillian. 1966. Illiberal Liberal : Robert Lowe in New South

Wales, 1842-50.

Melbourne: Melbourne University Press, 1966.

Leslie, T.E.Cliffe. 1879. "Political Economy and Sociology", repr. in Essays in Political 
Economy, (2 ${ }^{\text {nd }}$ ed.) London: Longmans, 1888

Lowe, Robert. 1867. Speeches and Letters on Reform. London: Bush

Lowe, Robert. 1868. "What Shall We Do for Ireland?” Quarterly

Review, 124: 255-86 Lowe, Robert. 1877. "A New reform Bill”,

Fortnightly Review , 22 (new series): 437-52

Lowe, Robert. 1878. "Recent Attacks on Political Economy",

Nineteenth Century, 4:

858-68

Lowe, Robert. 1879. "Reciprocity and Free Trade”, Nineteenth

Century, 5: 992-1002

Maine, Henry. 1876. Village Communities in East and West London :

Murray , $3^{\text {rd }}$ edition

Martin, Arthur Patchett. 1893. Life and Letters of the Right

Honourable Robert Lowe,

Viscount Sherbrooke,. (2 vols.) London: Longmans.

Mill, John Stuart. 1870. "Leslie and the Land Question" reprinted in

J.M.Robson

(ed.), The Collected Works of John Stuart Mill vol.5. Toronto:

University of Toronto

Press, 1967.

Moore, G.C.G. 1996. "Robert Lowe and the role of the vulgar

economist in the English 
Methodenstreit", Journal of Economic Methodology, 3

(December): 69-90

Morley, John. 1910. The life of Richard Cobden. London : T. Fisher

Unwin

Political Economy Club. 1876. Revised report at the proceedings at the Dinner of 31 st

May, 1876. London

Steele, E.D. 1991. Palmerston and Liberalism. Cambridge:

Cambridge University Press

Sylvester, D.W. 1974. Robert Lowe on Education. Cambridge :

Cambridge University

Press

Winter, James. 1976. Robert Lowe. Toronto : University of Toronto

Press

\section{FOOTNOTES}

1 History of the Times, London 1936-9, vol. 2, pp.131 ff. There is only one instance in

the letters of Delane telling Lowe what to write: Delane wanted an editorial on some

negotiations taking place with Canada, and urged Lowe not to "throw too much cold

water upon it." Lowe complied with the first part of the request, but refused the

second. Where Lowe's own feelings were not engaged he was willing to be a

"passive instrument" ; and on another occasion he checked that Delane's view 
concurred with his own before writing anything. As for editorial alteration of

Lowe's leaders after he sent them in, there is one instance of Lowe approving a piece

of editing as actually amplifying his own view, and one of Lowe regretfully informing

Delane that no change could be made as the leader was already in the press. On the

other side of the coin, Lowe was more than willing to tell Delane what to write,

notably in 1863 when Delane had got drawn into a long-running row between Cobden

and Lowe. Later Delane received a severe rebuke for being insufficiently hostile to the

Second Reform Bill. The friendship between the two men was

close (it was in Delane

that Lowe chose to confide the details of his deteriorating marriage) but the

correspondence reads as if neither forgot that Delane had once been Lowe's pupil at

Oxford .Delane Papers, News International Archives, JTD 12/136 (21\& 23

December 1863), 14/16 (12 \& 13 June 1865), 14/109 (15 December 1865), $15 / 6(10$

January 1866), 15/41 (28 March 1866), 15/62 (28 June 1866), 16/12 (22 January

1867).

2 Hansard, $3^{\text {rd }}$ series, 126, 935, 2 May 1853

3 For more on the political background to the treaty, see Morley

(1910), Iliasu (1965) and Howe (1997).

4 "Commercial Diplomacy, 1860-1902", printed for private circulation by the Foreign

Office, 1902. Public Record Office, Treasury Papers 172/945, p.5

5 In his Parliamentary speeches of 1865-7, opposing the extension of the franchise,

Lowe made much more of the link between democracy and protectionism than he ever

did in The Times. "Protection ... is the political economy of the poor, simply

because they are not able to follow the chain of reasoning which demonstrates that they 
themselves are sure to be the victims of the waste of capital which protection implies."

(Lowe, 1867, p.10) And anyone who wanted to see how democracy extinguished free

trade need only look at Canada, New South Wales, Victoria and above all the U.S.A.

(ibid., p.149)

6 Times, 11 June 1866, p.8, 1 August 1860, p.8, 23 January 1860, p.6;

Lowe to Sir

John Simon, 31 October 1868, quoted in Sylvester (1974) p.23 ;

Times, 27 February

1860, p.6, 11 August 1865, p.6, 8 December 1859 p.6; Hansard, 190, 1493, 12 March

1868.

7 Hansard., $3^{\text {rd }}$ series, 183, 1078 (17 May 1866)

8 Mill, too, saw emigration as at any rate part of the solution to Ireland's problems. The

main opponent among economists was Cliffe Leslie, who rejected emigration as a

misconceived inference from a misconceived doctrine (the wage fund) and a "waste of

industrial power and national strength" (Black, 2002 p.30)

9 Hansard, $3^{\text {rd }}$ series, 190, 1525, 12 March 1868

10 ibid., 1526

11 ibid., 1525-6

12 ibid., 1493

13 Lowe's interpretation of Smith particularly incensed Frederic Harrison, who had not been present at the centenary dinner but who wrote of the published proceedings that

"Lowe's sordid cunning came out in all its nakedness" (1/82/16, Harrison to Morley,

June 1876, LSE archives).

14 Cliffe Leslie rightly found this concession of Lowe's inadequate, pointing

out that chapter 1 of The Wealth of Nations "bears all the marks of wide research and 
induction." Of course Smith did not set before the reader every historical and statistical

fact he had discovered. "A discoverer would be avoided like the pestilence if he did

this" and no doubt this kind of thing was in the papers Smith had burnt shortly before

he died (Leslie 1879, pp.206-7)

15 This, as Cliffe Leslie was to point out, was essentially the same as Bagehot's

position, though Bagehot went further than Lowe and limited political economy to

"England at its present state of commercial development and to the male sex in

England." (Leslie1879 p.207). Leslie said that this, if accepted, proved on its own

that political economy began with induction -- the induction needed to decide which

societies were ripe for the political economy treatment. Bagehot agreed with this last

point, and there is no reason to think Lowe would have objected either. It was, in

fact, a common position in late nineteenth-century political economy, and Sir Henry

Maine, whose study of comparative law did so much to advance this attitude in the

work of others, held it strongly himself (see, e.g., "The Effects of Observation of

India on Modern European Thought", his Rede Lecture at Cambridge University, 1875, reprinted in Maine, 1876).

16 Lowe (1877) quoted in Martin (1893), vol. 2, p.445.

17 ibid., p.445 